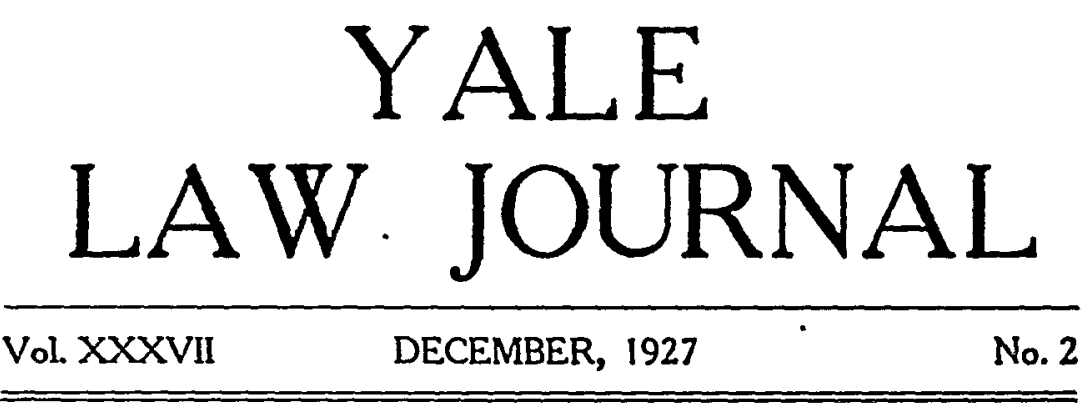

\title{
LEGAL AND ECONOMIC JOB ANALYSIS
}

\section{JoHN R. COMMONS AND E. W. MoRehouse}

Examination of legal and economic literature reveals two different views of job-transactions. The prevailing legal concept seems to be that the job is a contractual relationship between two individuals having an equal footing before the law. In contrast, the prevailing industrial concept of the job seems to be that of a bargaining relationship between unequal individual members of groups, concerning the disposal and conditions of opportunities to work. Both views grow out of past experience. The legal view originated in the customs and practices of master and servant; these have been modified here and there as the more up-to-date customs of employers and employees have been deemed sufficiently general and certain to warrant incorporation into the law. The contract of a master with his servant was like the contract between the buyer and seller of a commodity. This parallel is still dominant in the more modern law of employers and employees, and the courts do not seem inclined to permit a classification which distinguishes the labor contract from the commodity contract. Economists, however, are familiar with the distinction that in the labor contract the worker delivers himself on the job, whereas, in the commodity contract, the seller delivers to the buyer something separable from the person.

Courts and attorneys seem to visualize the worker in a world of equal legal opportunities, whereas the worker experiences only unequal, limited economic opportunities. As long as the law sets up the same legal obstacles to complete freedom of contract for employers and workers, the law need not, indeed cannot, concern itself with what the parties do to each other.' But the

1 ". . . . it is said by the Kansas Supreme Court (87 Kansas, p. 759) to be a matter of common knowledge that 'employees, as a rule, are not financially able to be as independent in making contracts for the sale of their labor as are employers in making contracts of purchse thereof.' No doubt, wherever the right of private property exists, there must and will be inequalities of fortune; and thus it naturally happens that parties negoti- 
difference in bargaining power causes the economic consequences of identical legal rules to vary widely for employers and workers. ${ }^{2}$ In other words legal equality and economic equality are not identical.

Another distinction centers in the res of the job-transaction. Before the law the job-contract determines legally enforceable rights and duties ${ }^{3}$ supported by remedies granted by the courts. But to the average worker the job-bargain determines what kind of living he can get in the struggle for life. Hence, to the worker, the opportunity of getting the courts to enforce employer's' promises is subordinate to the opportunity to get work on the best terms possible.

It is possible also to discern a difference with regard to the time element. The law looks to the past to find legal validity for the rights and duties of the contract, and to find what rights and obligations were mutually exchanged. The parties themselves look to the future to find economic security for their expectations.

The above statements are but various ways of expressing the clash between judicial and industrial practices, customs, and working rules-a clash which frequently is argued back and forth in the courts. From the broadest social point of view, in analyzing the job we deal with the task of harmonizing legal and economic institutions. How does the law affect economic behavior? How can legal customs be modified to meet the practical needs of the parties enlisting the aid of the courts? From an economic point of view we observe that the clash between the working rules of employers and of workers, when submitted to the law, results frequently in decisions which aggravate the problems of efficiency, good will, and stability.

The experience of the Rochester men's clothing market from 1919 to 1922 is brought forward as an illustration of the concept of the job as a bargain and of the process of stabilizing the

ating about a contract are not equally unhampered by circumstances. This applies to all contracts, and not merely to that between employer and employee. Indeed, a little reflection will show that wherever the right of private property and the right of free contract co-exist, each party, when contracting, is inevitably more or less influenced by the question whether he has much property, or little, or none; for the contract is made to the very end that each may gain something that he needs or desires more urgently than that which he proposes to give in exchange. And, since it is self-evident that, unless all things are held in common, some persons must have more property than others, it is from the nature of things impossible to uphold freedom of contract and the right of private property without at the same time recognizing as legitimate those inequalities of fortune that are the necessary result of the exercise of those rights." Coppage v. Kansas, 236 U. S. 1, 17, 35 Sup. Ct. 240, 244 (1915).

2 See State v. Coppage, 87 Kan. 752, 755-6, 125 Pac. 8, 9 (1912).

31 WILliston, Contracts (1920) §§ 1,$2 ; 2$ ibid. c. 30; ANSON, CoNTRaCTS (Huffcut ed. 1903) $\S \S 4,6,7,9$. 
bargaining relations between employers and employees by the development of working rules through extra-judicial arbitration machinery. The footnotes will show corresponding legal opinions.

There are at least three reasons for the selection of the period 1919-1922: (1) During these three years the Rochester clothing market experienced both prosperity and depression; (2) The jurisdiction of the arbitrator was broad ${ }^{4}$ and reports of cases were relatively complete; (3) After 1922 the jurisdiction of the arbitrator was narrowed 5 and reports of cases were so brief as to make it impossible to analyze the situation from the published record alone.

From 1919 to 1922 bargaining was carried on under two agreements. ${ }^{6}$ The first and more or less informal agreement was negotiated in February, 1919 between a group of employers, organized as the Rochester Clothiers' Exchange, and the Amalgamated Clothing Workers ${ }^{7}$ while the latter organization was en-

4 AgREenIENT FOR 1920-1922, Sec. 9: "The board (Labor Adjustment Board) shall have authority to make such rules, regulations, and supplementary arrangements not inconsistent with this agreement as may be necessary to carry into effect the principles of this agreement or to apply these principles to new situations whenever they arise. It may also define, describe and limit the penalties to be imposed for the violation of any of the provisions of this agreement.

Sec. 8: “. . . All disputes or differences over questions arising under this agreement which the parties hereto are unable to adjust between themselves shall be referred to the Labor Adjustment Board for adjustment or arbitration. This board shall have full and final jurisdiction over all such questions, and its decisions shall be conclusive, except as may be otherwise provided by agreement between the parties hereto. Except where the board itself shall otherwise determine, the chairman of the board shall be authorized to take original jurisdiction of all cases and controversies arising under this agreement and to adjust or decide them in accordance with rules of practice and procedure established by the board. Decisions of the chairman shall be binding on both parties ..."

"AGREEMENT FOR 1922-1925, \& 11: ". . The duties and jurisdiction of the arbitrator are fixed and linited by this agreement. He shall have no power to enlarge such jurisdiction unless by mutual consent of the two parties to this agreement. ..."

c A strike in 1913, involving members of the United Garment Worliers, was settled partly through mediation by state oficials. The terms of settlement included dealing with committees of employees, but not recognition of, or dealings with, the union. Winslow, Collcetive Agrccincnts in the Men's Clothing Industry, Bulletin 198, U. S. Bureau of Labor Statistics (1916) 144-149.

Labor difficulties with two firms in 1918 led to the Ripley-Kirstein award. The adjustment machinery established to work out this award prepared the way for negatiating the agreement in 1919 without a strike. For one account of the Ripley-Kirstein award, see Refort of Generar ExicuTrve

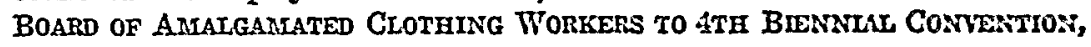
BOSTON, 1920, 39-43.

i Agreements were negotiated on behalf of the members of the local 
gaged in strikes to secure the 44-hour week and market agreements in Chicago and New York. This agreement, effective from April 1, 1919 to May 1, 1920, provided for the "open shop," collective bargaining through shop chairmen or outside representatives of the union, a procedure for handling complaints, arbitration of unsettled disputes by a jointly chosen and jointly paid arbitrator, the 44-hour week, and negotiation or arbitration of wage scales. ${ }^{8}$

A two-year agreement followed in May, $19200^{\circ}$ This agreement carried on most of the principles worked out during the first year, including the open shop feature, and established some new principles. It included specific hiring, discharge, and equal division of work clauses; recognized the employer's right to make changes in manufacturing methods; established the princi-

unions by the Joint Board, usually acting with the advice and assistance of the national president of the union. Under Art. XIV, § 14, of the Constitution of the Amalgamated Clothing Workers, "All acts of the Executive Board (i. e., of the local union, or the Joint Board of the locals in a district) shall be subject to the ratification of the organization." By the same clause of the constitution, "in cases where a boycott is considered necessary by the local Executive Board the matter shall be submitted to the General Executive Board, or the General Convention, for approval and action." By Art. XI, § 1, strikes had to be submitted to the General Executive Board of the Union for endorsement.

These provisions of the Union's constitution are cited because one of the questions raised in juridical consideration of a collective agreement, such as a contract, is the extent of the power of union officials to bind members. The power of union officials to act as agents in the formation of trade agreements or otherwise, so as to bind the union membership and possiblo outsiders, depends upon the general laws of agency. For a statement of the agency doctrine as to union officers, see WRIGHTINGTON, UNINCORPORATED ASSOCLATIONS AND BUSINEss Trusts (2d ed. 1923) \& 67; Grinnel, Analysis of Legal Value of a Labor Union Contract (1907) 41 AM. L. REv. 197, 206; 24 Cyc. 824; 16 R. C. L. 425; SAYre, Cases on Labor Law (1922) c. 13. See also the following cases which illustrate the application of the agency doctrine to disputes involving construction of collective agreements. Barnes \& Co. v. Berry, 169 Fed. 225 (C. C. A. 6th, 1909) (power of offcials to negotiate binding agreement must be expressly authorized); Burnetta v. Marceline Coal Co., 180 Mo. 241, 79 S. W. 136 (1904); Hudson v. Cincinnati, New Orleans and Texas Pacific Railway Co., $152 \mathrm{Ky} .711,154 \mathrm{~S}$. W. 47 (1913) (officials may not bind individual members without their express assent); Langmade v. Olean Brewing Co., 137 App. Div. 355, 121 N. Y. Supp. 388 (4th Dept. 1910) (the specific provisions of individual employment contracts override conflicting provisions of the collective agreement); SauIsberry v. Coopers' International Union, $147 \mathrm{Ky} .170,143$ S. W. 1018 (1912) (union alone empowered to make agreements regarding the use of the union label).

8 A written version of this understanding may be found in the REPORT OF

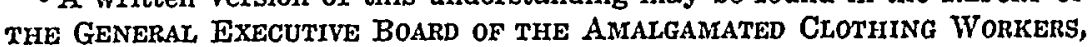
op. cit. supra note 6 , at $45-46$.

9 The full text of the written agreement may be found in (1920) 11 MONTHLY LABOR REv. 1220-1221. 
ples of a minimum wage and the abolition of home work; created administrative machinery for handling disputes, exercising sanitary control of shops, and developing supplementary rules governing new situations; and specified the procedure by which changes in wage levels and wage rates should be made. The agreement briefly stated the general principles according to which bargaining should be carried on from day to day. Being in general terms, it was inevitable that disputes over the application of the agreement to specific conduct should arise. The process of adjusting these disputes required continuous collective bargaining and arbitration machinery and resulted in new interpretations which amplified the general rules of the agreement.

The machinery of collective dealing was simple. The employees in each shop elected a representative to take up complaints with the foreman or labor manager, in the first instance. If no agreement was reached, the shop chairman called in a business agent of the union. If still no agreement was reached, the next step was to refer the matter to the Labor Adjustment Board of the market. This board was composed of the business agents of the union, the labor managers of the various firms in the Clothiers' Exchange, and an "Impartial Chairman" selected and paid jointly by the union and the employers' organization. Representatives of employers and representatives of workmen usually voted as a group; in case of a tie the Chairman cast the decisive vote. The Board had final jurisdiction and a decision of the Impartial Chairman was binding on both parties. In practice the Chairman functioned as an arbitrator having both original and final jurisdiction.

The employers had agreed to give up a measure of their control over jobs. But even under this general concession an individual worker in Rochester found his job-opportunities menaced by several risks: (1) the risk that a non-union or out-of-town worker might get a job ahead of him; (2) the risk that tenure of the job (continued opportunity to earn a living) might be terminated by his employer, other employers, or other workers; (3) the risk that opportunities to work might be withdrawn for a longer or shorter period; and (4) the risk that opportunities to capitalize skill and experience might be destroyed by changes in manufacturing technique.

To reduce the first risk it was agreed to establish for Rochester union workers preferential access to opportunities to work. To modify the second and third risks it was agreed to establish detailed rules indicating when and under what circumstances occupancy of the job might be terminated, either permanently or temporarily. The fourth risk could not be eliminated but its 
harsh effects might be softened. The cases which are subsequently analyzed are grouped according to the following scheme:

1. Access to job-opportunities

2. Tenure of job-opportunities

a. Individual discipline

1) Workers

2) Officials

b. Group discipline

c. Lay-off and permanent reduction of force

d. Introduction of machinery.

\section{ACCESS TO JOBS-HIRING TRANSACTIONS}

The hiring clause of the agreement stated:

"The power to hire shall remain with the employer, but in cases where discrimination on account of union membership is charged, the Impartial Chairman shall have the right of review; and if facts are brought before the Impartial Chairman that appear to indicate that the labor policy of any house is calculated to undermine the union, he shall have the power to review that policy." 10

On its face this clause established an open shop in which union men and non-unionists should receive equal treatment. There were, however, two supplementary understandings which made this clause more specific. One was that the first two weeks of employment would be regarded as a probationary period during which the employer might discharge freely; the other was that during unemployment employers would give opportunities to work to Rochester workers in preference to out-of-town workers.

The earliest cases arose from charges of blacklisting. ${ }^{11}$ In

10 Omitting supplementary agreements regarding notice of discharge or quitting, (infra p. 16). the individual contracts of employment made under this clause were so-called contracts at will. More specifically, the legal relations of employers and employees, as individuals, were embodied in a series of unilateral contracts to pay for work done. In New York the rule, with a few exceptions, is that a contract of service for no stipulated time is a hiring at will which creates no legal obligations on either party to continue the relations in the future, that is, creates no mutual executory obligations. In Rochester this rule might be varied because of the clear, though unwritten, understanding that a week's notice should be given before discharge or quitting. 2 WuLIsToN, op. cit. supra note $3, \S 1027$. Tho courts are divided on the question whether, in the absence of an express stipulation, a term may be presumed from the weekly payment of wages. 1 Williston, op. cit. supra note $3, \S 39 ; 39$ C. J. $\S 18$. Whether a term may be presumed by reason of the duration of the collective agreement was discussed in Hudson v. Cincinnati Ry., supra note 7, the court holding that the collective agreement did not bind members to serve for any definite period.

11 Compare the arbitral treatment of alleged blacklisting with the legal 
Case $64^{112}$ the union complained that a worker was refused employment after two weeks' work because a labor manager told the employer that the worker could not be hired.12 The hearings disclosed that the worker had been fired after several days work, re-employed within a half a day, worked two weeks, and was then let go at the instigation of a labor manager. There were no charges that the worker had left his previous employer without a week's notice. In the absence of such charges, the arbitrator ruled that the worker could not be denied employment, and ordered him reinstated with pay for time lost.

treatment in Boyer v. Western Union Telegraph Co., 124 Fed. 246 (E. D. Mio. 1903) (employer's blacklist of union men not remediable in equity); Goldfield Consolidated Mines Co. v. Goldfield Miners' Union No. 220, 159 Fed. 500 (D. Nev. 1908) (agreement among mine operators not to employ members of the union held not to be an unlawful conspiracy; a statute similar to that involved in Coppage v. Kansas, supra note 1, being declared unconstitutional); Willner v. Silverman, 109 IId. 341, 71 Atl. 962 (1909) (black-list which prevented plaintiff from securing employment held an actionable wrong for which plaintiff might sue for damages).

11 These cases are reported in mimeograph form by the Rochester arbitrator chiefly for the information and guidance of the parties to the agreement in the local market Cases are numbered as complaints are filed with the arbitrator and these docket numbers have been used throughout the article. The writer prepared a digest (unpublished) of the written opinions of the arbitrator during the first three years of the collective agreement. Occasionally significant opinions of the arbitrator are currently noted in the MoNThLY Labor REview, of the United States Department of Labor.

12 The Clothiers' Exchange established a central clearing house for listing the employees of each firm. Notices of accessions to, and separations from, the payroll of each firm were sent to the Exchange. Prior to hiring any individual worker, the custom was for an employer to telephone the Exchange and obtain a "release" on the worker from the previous emploger. In this manner a check was kept on the worker's conformity to the wcel?'s notice rule. Since the arrangement was instituted in a time of labor shortage, it also served in a measure to protect employers from the temptation to "steal labor" by raising wages. When shops started up after the "between-season" slump, the clearing house system was of some assistance to employers needing new workers. Furthermore, it affordcd to the arbitrator a check upon the bare facts of employment, which were somctimes disputed in cases involving discharges during the probationary period and quitting without notice. In hiring, no questions were asked regarding union affiliations. Compare Street v. Shipowners' Association of Pacific Coast, 203 U. S. 334, 44 Sup. Ct. 119 (1923); Anderson v. Shipowners' Association of Pacific Coast, 272 U. S. 359, 47 Sup. Ct. 125 (1926) (in which the operations of an employers' association registration bureau were dcelared within the scope of the Sherman Act) ; Industrial Association of San Francisco v. United States, 268 U. S. 64, 45 Sup. Ct. 403 (1925), rcr'g 208 Fed. 025 (N. D. Cal. 1923) (in which use of "permit system" controlling access to materials, for the purpose of effecting the "open shop" in the local building industry, was held not to interfere with interstate commerce); Tilbury $v$. Oregon Stevedoring Co., 7 F. (2d) 1 (C. C. A. 9th, 1925) (in which an 
In Case 115, a worker gave notice of quitting, intending to get a custom job at higher wages. This opportunity was withdrawn at the request of some member of the firm for which he had worked. The worker subsequently obtained another job from which he was suspended at the request of a labor manager. Complaint was therefore made of unjust discrimination in hiring. The arbitrator ruled: "The worker violated no agreement when he gave a week's notice because he had a better job." Since the arbitrator was unable to fix the responsibility for loss of time on any one individual, the Clothiers' Exchange was ordered to compensate the worker.

In Case 122 a worker was discharged after working one week, at the request either of a former employer or the Clothier's' $\mathrm{Ex}$ change. ${ }^{13}$ The arbitrator ruled that the employer's right to discharge during the probationary period was not absolute, but limited by the "spirit and purposes of the agreement." In the language of his decision:

"Such discharges whether made during the first week of employment or at any other time, cannot be approved ... The right to discharge during the first two weeks must be limited by the spirit and purposes of the agreement. If this right were held to be absolute so that an employee who has done nothing wrong, and whose work is satisfactory to the employer, may be discharged at the instigation of other employers, then a blacklist of the worst kind would be legalized. At the same time the right of the Union to tell its members where they may or may not work would also have to be considered an absolute right, so that it might keep workers from going to certain factories and thus tie up shops as effectively as if a strike were called." 14

In Case 139 a worker had quit without notice, and the contractor who employed him had not insisted upon a week's notice. Subsequently another employer refused to hire this worker because he had not given a week's notice to the contractor. The worker lost time until the contractor notified the Exchange that he had acquiesced in the quitting without notice. This was held to be an invasion of the worker's rights.

employers? registration system, which prevented plaintiff from obtaining employment, was held not to be an obstruction of interstate commerce).

13 The situation was similar to that in Willner v. Silverman, supra noto 11. Compare with State v. Justus, 85 Minn. 279, 88 N. W. 759 (1902), sustaining an anti-blacklisting statute. As to the efficacy of such statutes, see Commons \& ANDrews, Principles of Labor Legislation (3rd ed. 1927) $123-125$.

14 In Carnellier v. Haverhill Shoe Manufacturers' Association, 221 Mass. 554, 109 N. E. 643 (1915), a blacklist was declared illegal and likened to a boycott, Worthington v. Waring, 157. Mass. 421, 32 N. E. 744 (1892), being overruled. 
"Employers who give references on any employees who leave them must be careful to tell the exact truth ${ }^{15}$ as to whether they quit with or without notice and no one has a right to interfere with any workman getting another job."

In Case 210 a worker was hired by a foreman and told to report for work the following day, at which time he was refused employment because he had worked for and quit the firm before. There was no evidence of blacklisting.

"Under the circumstances the Chairman does not think it wise to reinstate the man, as the firm could discharge him again within the two weeks' probationary period."

Three decisions pertaining to preference in hiring ${ }^{16}$ during slack employment followed the above cases. In two of the three the transaction also involved alleged discrimination against nonunion men.

In Case 230 a firm hired an out-of-town sleeve sewer when two former sleeve sewers of the same firm were unemployed. The union contended that with Rochester sleeve sewers out of work, the firm was obligated to hire one of them in preference to the out-of-town worker, according to the informal understanding. The arbitrator found that the firm had sent for both local workers, one of whom quit and the other left town. He therefore ruled that the firm had fulfilled its obligations under the informal agreement and was privileged to hire the out-oftown worker. ${ }^{17}$

15 Probably an injurious false statement regarding discharge is actionable even in the absence of statutes. Willner v. Silverman, supra note 11. A statute was involved in Hundley v. Louisville \& Nashville Railroad Co., $105 \mathrm{Ky} .162,48 \mathrm{~S}$. W. 429 (1898), in which a false statement of the reason for discharge was held actionable. The Missouri Service Letter Act, which required corporations doing business in the state to give discharged or quitting employees, upon request, a letter stating the work performed and cause of separation, was upheld in Prudential Insurance Co. v. Cheek, 259 U. S. 530, 42 Sup. Ct. 516 (1922).

${ }^{16}$ In the absence of other faults, a preferential shop agreement is clearly lawful. Underwood v. Texas \& P. R. Co., 178 S. W. 38 (Tex. Civ. App. 1915). A preferential shop agreement was involved in Schlesinger $v$, Quinto, 201 App. Div. 487, 194 N. Y. Supp. 401 (1st Dept. 1922), in which the union obtained an injunction restraining an employer's breech of the collective agreement.

17 Where an agreement allows an employer to hire in the open marliet if the union is unable to furnish workers (a common form of agreement), an employer will not be enjoined from exercising this option. Goyette v. Watson Co., 245 Mass. 577, 140 N. E. 285 (1923). But the result is practically a closed shop, for the union usually tries to organize such nonunionists as rapidly as possible, and non-unionists are induced to join through hope of getting better terms of employment, by limiting competition for jobs, and by union protection of the job, or through fear of losing their jobs. Not infrequently a trade agreement specifically requires 
In Case 455 the union complained that a presser, who had been expelled from the union, was hired by a firm when there were other local seam pressers out of work. The firm argued that the worker in question had had Rochester experience before leaving town for Europe and that the union had not filled the firm's requisition for a presser. The ruling was that if the union could furnish a presser at once, ${ }^{18}$ he should be given prior consideration..$^{10}$

In Case 801 the union complained that a recently hired offpresser had no right to the job because of unemployment in that operation. The worker had been an assistant foreman in another house and hence not a union member. Before that he had worked as an off-presser for the employer who had just hired him. The arbitrator cited the "unwritten understanding that when there is unemployment in any craft no worker of the same craft shall be given a job if he does not already belong to the industry in this market." The worker in question was not a learner" ${ }^{20}$ nor a non-resident. He had "belonged to the industry

the employer to dismiss new employees who do not join the union within a stated time. A strike to enforce such a provision was declared lawful in Greenfield v. Central Labor Council, 104 Or. 236, 192 Pac. 783 (1020). But such an agreement has been held void as in restraint of trade, and therefore no defense to the union officials, in a suit for damages by a worker who was discharged at the instigation of union officials becauso he did not join the union within the time limit. Curran v. Galen, 152 N. Y. 33, 46 N. E. 297 (1897) ; Berry v. Donovan, 188 Mass. 353,74 N. E. 603 (1905).

18 In Barzilay \& Harris v. Loewenthal, 134 App. Div. 502, 119 N. Y. Supp. 612 (1st Dept. 1909), the Appellate Division of the New York Supremo Court reversed an order that the union furnish workers, not otherwise employed, according to a clause of the agreement, because, among sovoral reasons, "no one but the employer's association can enforce the agreement and it is doubtful whether it can be enforced by injunction at all."

${ }^{10}$ In Shinsky v. Tracey, 226 Mass. 21, 114 N. E. 957 (1917), a union agent was held liable in damages to a worker who was discharged from his job after being expelled from the union for joining a rival union. An injunction was also issued, and the collective agreement was held to be no defense. The court likened the action of the union to a boycott, adding, "the right to acquire property by labor is co-equal with the right to acquire property by contract." To the same effect, see Connors v. Conholly, 86 Conn. 641, 86 Atl. 600 (1913) ; Berry v. Donovan, supra noto 17. But the same worker, being unable to secure employment, was denied a remedy against union officials because the refusal of employment by the employer was in support of a valid trade agreement and the acts of union officials were not malicious. Shinsky v. O'Neil, 232 Mass. 90, $121 \mathrm{~N}$. T. 790 (1919); Hoban v. Dempsey, 217 Mass. 166, 104 N. E. 717 (1014). An employer was not enjoined from refusing to employ non-union workors as required by a closed shop agreement in Mills v. United States Printing Co., 99 App. Div. 605, 91 N. Y. Supp. 185 (2d Dept. 1904), and Kissam v. United States Printing Co., 199 N. Y. 76, 92 N. E. 214 (1910).

20 In Ryan v. Hayes, 243 Mass. 168, 137 N. E. 344 (1922), an inoxperienced worker was hired on condition that he join the union. After 
for years both through learning his craft in it and by employment" and hence "under the agreement he has a right to this position." 21

The hiring clause, minus the supplementary understandings, sanctioned the prevailing practices of employers, with the exception of the limitation upon the privilege of discriminating on account of union membership. The purpose of this limitation was obviously to equalize bargaining strength in order that the agreement might work successfully. This is a valid object when reached by a trade agreement, but not valid as a legislative object, enforced by fine or imprisonment." A clear case involving only the fact of discrimination on account of union membership did not arise. It was one of the elements in Cases 455 and 801, one ruling favoring the union, the other the nonunion worker. ${ }^{23}$

The blacklisting cases involved chiefly the problem of justifiable interference with employment by third parties." It appears

joining, the union required that he take his turn with other members seeking jobs. He was denied damages and an injunction for an alleged conspiracy on the part of the union to prevent him from obtaining and holding his job.

21 In Smith v. Bowen, 232 Mass. 106, 121 N. E. 814 (1919), a strike to prevent continued employment of a non-union worker, formerly foreman in a shop in another city, when competent union workers vere unemployed, was held unjustifiable in the absence of a closed shop clause in the agreement.

22 Coppage v. Kansas, supra note 1; Adair v. U. S., 208 U. S. 161, 23 Sup. Ct. 277 (1908) ; People v. Miarcus, 185 N. Y. 257, 77 N. E. 1073 (1906).

${ }^{23}$ In Case 555 a girl was discharged for repeated tardiness and quarrelling with other workers. The union claimed discrimination on account of union membership, but since no evidence supporting this claim was submitted, the discharge was upheld.

${ }^{24}$ The legal treatment of interference with employment by third parties is unsettled and unsatisfactory, despite the decision of the majority of the United States Supreme Court in Hitchman Coal \& Coke Co. v. Mitchell, 245 U. S. 229, 38 Sup. Ct. 65 (1917). The complexity of modern economic relations, the widening of markets and of competitive influences, and the rapidly changing customs of associated activity, are some of the factors that have made it difficult for the courts to protect beneficial relations between individuals from interference by other individuals and groups. One source of difficulty seems to be that the courts often cling to the idea that competition in the "struggle for life" is still between individuals, whereas, as a matter of fact, individuals nowadays act chiefly as representatives of groups, backed by the power of the group.

In general, inducing a breach of contract is held to be actionable. Sayre, Inducing Breach of Contract (1923) $36 \mathrm{HARV}$. L. REv. 663, 666. Inducing the termination of a contract as well is also generally actionable in the absence of justification. Infra note 37. The arbitration cases mentioned above are comparable to the cases in which inducing the non-formation of a contract is actionable if unlawful means be used, or if the motive is to injure others and not benefit the actor. Strikes, picketing, and boycotts, the common weapons of unions in forcing employers to meet their 
that a worker's access to employment opportunities was protected from arbitrary and unreasonable interference by other employers, despite the apparently large scope of the employer's privilege to discharge at will during the two weeks' probationary period. Such interference was justifiable if for the purpose of protecting the common rule of giving a week's notice before quitting (Cases 64, 115, 119, 139). Otherwise it was "malicious" in that the interference had no clear relation to legitimate trade advantages of the employer, and bad policy because it tended to provoke retaliatory acts on the part of the union (Case 122).

terms, are, of course, interference by third parties with the formation of individual contracts. The difficulty lies in the fact that such activitles always injure others more or less, for they invade the employer's right of free access to labor and commodity markets, which right the courts have found it necessary to protect in order to preserve "free competition." Permissible interference with this right varies greatly in different states. SAYRE, op. cit. supra note 7, c. 4-10.

The above arbitration cases, which tended to circumscribe the employer's right to hire whom he pleased and the out-of-town workers' right of access to employment opportunities in Rochester, involved only peaceable means, $i$. e., persuasion. Some courts, however, have enjoined even persuasion not to enter employment, because it interfered with an employer's right to unhindered access to the labor market. Sherry v. Perkins, 147 Mass. 212, 17 N. E. 307 (1888) ; Vegelahn v. Guntner, 167 Mass. 92, 44 N. E. 1077 (1896) ; Jersey City Printing Co. v. Cassidy, 63 N. J. Eq. 759, 53 Atl. 230 (1902) ; Frank \& Dugan v. Herold, 63 N. J. Eq. 443, 52 Atl. 152 (1902); Brennan v. United Hatters, 73 N. J. L. 729, 65 Atl. 165 (1906). It is to be noted that these cases are not very recent. But in Carnes v. St. Paul Union Stockyards Co., 164 Minn. 457, 205 N. W. 630 (1925), the court intimated that interference which prevented the formation of employment contracts might be unlawful unless justified by legitimate trade interests. In this case the means used were beyond doubt lawful persuasion; the earlier cases illustrate nicely how much at variance judicial and industrial concepts of reasonable persuasion and economic coercion often are. In this connection one may also observe that some courts, following the principle laid down in American Steel Foundries v. Tri-City Central Trades' Council, 257 U. S. 184, 42 Sup. Ct. 72 (1921), have so narrowed the privilege of picketing that the possibilities of inducing by persuasion either the termination or non-formation of contracts are remote indeed. Jefferson \& Indiana Coal Co. v. Marks, 287 Pa. 171, 134 Atl. 430 (1926).

In New York, "assuming a justifiable motive (if that be necessary), it is not unlawful by persuasion, agreement, and entreaty, accompanicd by picketing, patrolling or spying, to induce a breach of contract, or the termination or non-formation of contract." Huffeut, Interference with Contracts and Business in New York (1905) 18 HARv. L. REv. 423, 431. But recent New York cases have held that peaceful picketing which prevents the formation of employment or commodity contracts may be enjoined. See Comment (1927) 36 Yale Law Journal 557. However, in Exchange Bakery and Restaurant v. Rifkin, 157 N. E. 130, 134 (N. Y. 1027), the New York Court of Appeals upheld the privilege of peaceful picketing, reversing the judgment of the Appellate Division, $216 \mathrm{App}$. Div. 663, 215 N. Y. Supp. 753 (1st Dept. 1926). 
The preference in employment cases involved third party interference of a different nature. In these cases the union sought to interfere with the reciprocal access to the labor market of employers and actual or alleged out-of-town workers. By the informal market understanding the union hoped to protect local workers from the potential or actual competition of outof-town workers. In effect, therefore, the parties agreed to a measure of restricted access to market opportunities in the interest of a strengthened union and a more or less stabilized market.25 But the interference with a free flow of labor in and out of the Rochester market did not, of course, extend to the point of an absolutely closed market $=0$ (Case 239), nor a closed union. The interpretation of the rule justified union interference with the job opportunities of non-resident workers (Case 230), those temporarily non-rèsident (and non-union) (Case 455), and resident apprentices (Cases $584,602,692$ ), but not of a resident worker who happened not to be a union member (Case 801).

\section{TENURE OF JOES}

(a) Individual discipline. (1) Workers. The discharge clause of the agreement (Sec. 4) was as follows:

"The power to discharge and suspend employees remains vith the employer, but it is agreed that this power will be exercised with justice and due regard for the rights of the workers; and if any worker feels that he has been unjustly treated in the exercise of this power, he may appeal to the labor adjustment board hereinafter mentioned, which shall have the power of review in all such cases."

The understanding about discharges at will during the first two weeks of employment amounted to a subtraction from this clause. ${ }^{27}$ After the probationary period discharges had to be

25 In Fairbanks v. McDonald, 219 Miass. 291, 106 N. E. 1000 (1914), the court approved an injuction and damages for interference with employment by rival unionists. The court said at 297: "In contemplation of law, they acted from malice towards the plaintiffs, and did to them an unlawful injury, by causing their exclusion from the labor market."

${ }^{26}$ In New York closed shop agreements which amount to a local monopoly appear to be illegal, but agreements with some, but not all, similar shops in the locality, are valid. (1924) 2 WIS. L. REv. 369. The courts generally seem to be about evenly divided when the closed shop policy involves a monopoly of an entire trade, making it difficult for a non-union rorlier to get a job. See Comment (1921) 30 Yale Law Jouraral 280, 285; Sartie, op. cit. supra note 24, c. 5; cf. Connors v. Connolly, supra note 19; Tracey v. Osborne, 226 Miass. 25, 114 N. E. 959 (1917).

$2 \pi$ As a matter of law, therefore, individual employment contracts during the two weeks' probationary pexiod were, strictly spealing, hiring at will. 1 WILLISTON, op. cit. supra note $3, \S 39$. 
justified ${ }^{28}$ and were subject to the week's notice rule ${ }^{20}$ unless the offense warranted summary dismissal. ${ }^{30}$

Since the agreement did not specify what were considered just causes, we have to seek the precise scope of this clause in the decisions of the arbitrator. We find that a worker was not to be discharged on account of poor quality of production ${ }^{31}$ when he was not given at least two weeks' fair trial on the new work (Case 296), when he was old (Case 159), when the shop chair'man's cooperation in securing improvement was not solicited (Cases $328,607,617,811$ ), when charges of incompetence were made after a lay-off to avoid re-employing the worker (Cases $38,285,338$ ), when a foreman relied on threat of discharge to bring about improvement (Cases 318, 582), when the worker received less than the scale of wages (Cases 88, 148, 159), and when the worker was not given fair warning of his deficiencies (Case 38). However, a worker was justifiably discharged for poor workmanship when he had been given a reasonable trial (3 months in Cases 161 and 588; 2 weeks in Case 296), or when he clearly could not do the work for which he was hired (Cases $39,279,315)$.

Similarly a worker was not to be discharged for lowv production when paid less than the scale (Cases 88,159 ), when production records did not prove the employer's case (Case 384), when the cooperation of the union was not solicited (Case 617), or when there was an adequate remedy in measured production (Case 332). Nevertheless, a worker was justifiably discharged for low production when production records clearly proved the case (Cases $315,588,617,645$ ), when an investigating committee representing both sides agreed a fair day's work for the wages paid was not being given (Case 153), when the worker deliberately restricted out-put (Cases 325,463 ), when the firm had used reasonable efforts to train the worker (Case 161), or when the worker was unable to earn even the minimum wage on fair rates (Cases 617, 645).

${ }^{28}$ Such limitations on discharge in collective agreements have not boen controlling unless the individuals concerned expressly contracted in reforence thereto. Hoey v. New Orleans and Great Northern Ry., 159 La. 258, 105 So. 310 (1925) ; Hudson v. Cincinnati Ry., supra note 7; cf. Caven v. Canadian Pacific Railway [1925] 1 D. L. R. 122; (1925) 38 HARv. L. REv. 833.

29 The week's notice rule, being generally known, would probably be controlling in law also. 2 Williston, op. cit. supra note $3, \S 1027$.

${ }^{30} \mathrm{As}$ to what, in the law, constitutes a material breach of duty of servant to master, justifying discharge, see 2 WiLuiston, op. cit. supra note $3, \S \S$ 1013-1014, 1017-1018, 1020-1022; 1 Labatt, Master and Servant (2d ed. 1913) $\S \S 268,273-274,288-299$; 39 C. J. $\S \S 79-90$.

31 Compare 2 WILLISTon, op. cit. supra note $3, \S 1014 ; 1$ LABATT, op. cit. supra note 30 , $\$ \$ 293-294$, on the legal duty to render "diligent and skillful service." 
Another group of cases concerned the employer's use of the discharge privilege in order to maintain shop morale. An employer was justified in dismissing a man who used physical violence in the shop (Cases 205, 226, 474), who smoked in the shop in violation of a clearly understood rule (Cases 35, 422), who was dishonest (Case 340), who refused to go to the labor manager to settle a dispute (Case 194), who refused to obey reasonable orders of the foreman (Cases 35, 232, 422), who refused to obey orders of foreman and shop chairman (Cases 85,715 ), who used indecent language in the shop (Case 85), who interfered with other workers (Cases 75, 123, 243, 555, 680 ), or who was repeatedly tardy and quarrelling with other workers (Cases 75,555 ). On the other hand, there was not sufficient cause for discharge when the smoking rule was not observed equally by members of the firm (Case 656), when the actions of the employer were a provocation to the worker (Cases 205, 257, 270), when "bad times" and the difficulty of finding another job made discharge for loafing unduly severe (Case 208), when the worker was comparatively young (Case $130)$, or when the employer was unable to prove his charges (Case 215).

Treatment of discharges for absence without notice to the employer varied according to the circumstances in each case. There was a market understanding to the effect that the worker must notify the firm within 48 hours if he wished to retain his jobprivileges. In an early case this understanding was interpreted by the arbitrator to mean two working days, i. e., the 48 hours should be reckoned from the time when the worker ordinarily would have reported for work (Case 27). If a sick worker relied upon a friend to notify the firm, he was liable to discharge if the friend could not clearly prove notification within the time limit (Case 147). Yet extenuating circumstances were recognized, as when an employer had recently raised wages despite irregular attendance (Case 251), or when a worker mistalienly believed Jewish holidays were excluded from consideration (Case 251 ), or the long service of employee (seven years) justified giving him another chance (Case 456). Where there were reasonable extenuating circumstances, the extreme penalty of discharge was sometimes modified to suspension (Case 251).

In discharges made necessary by over-manned sections, the employer was given considerable latitude, provided he exerted reasonable efforts to keep the excess number of workers employed, notified the union of over-manned sections, and gave the union a chance to find other jobs for the displaced workers (Cases 121, 385, 496, 594).

Similarly, in the cases involving transfers from one job to another, the worker "has a right to object to a demotion," but 
if the transfer was reasonable, such as to fill out a short-handed section (Case 442), the worker had no justification for refusing. However, where the transfer was from week work to piece work, two periods must be distinguished. Up to May 3, 1921, the arbitrator protected the worker from being forced to accept piece work against his will (Cases $38,193,228$ ). After that date, however, the management was given the privilege of transferring any worker or operation to piece work (General Award, May 3, 1921 and Case 535), provided the operation was susceptible to measurement (Case 529) and rate and earnings were fair compared with those in other firms in the market.

Discharges after a lay-off were generally not approved unless exceptional circumstances could be shown. In one case a worker was not rehired after a lay-off because his operation was abolished. This was held to be "no just cause for dismissal because the agreement, while leaving the employer free to change operntions as he sees fit, provides that the worker should not suffer as a result of such changes" (Case 306 ). Similar positive obligations were imposed on the employer to teach apprentices, and an employer was not warranted in discharging an apprentice if this obligation was not reasonably performed (Cases 98, 739). Finally, we may note that an employer was not justified in discharging a worker because he exercised his "right" to ask for increased wages (Case 100) or the minimum wage (Case 752).

Penalties for unjustifiable conduct varied with the seriousness of the offense and the circumstances of each case. The more serious offenses, which constituted just cause for discharge (generally associated with efficiency of production) were penalized by loss of jobs. Lesser offenses called for suspension for a certain time or reinstatement without pay for time lost in hearing the case. Where the employer was wholly unjustified in his disciplinary action, the worker was reinstated with pay for time lost, which amounted to an award of compensatory damages without the worker's duty of mitigation..$^{32}$

A few striking cases reveal more clearly the process of changing the working rules by arbitral interpretation. Most of the

\footnotetext{
${ }^{32}$ In Hoey v. New Orleans Great Northern Railroad Co., supra noto 28, plaintiff had been discharged in violation of an agreement with his union. The Railroad Labor Board recommended reinstatement and defendant no. tified him to return to work, but plaintiff failed to return to work because of a strike involving his craft. The court held that the plaintiff was entitled to wages during the period of wrongful discharge until notified to return to work, the defendant by such notice having accepted the decision of the arbitration board. In Hudson v. Cincinnati, New Orleans \& Texas Pac. Ry. Co., supra note 7, a trade agreement was held not to bo a contract upon which the plaintiff could rely in an action for damages for wrongful discharge in violation of agreement, for the agreement was merely a memorandum of usages.
} 
above cases involved the relations of economic opposites acting as individuals; the union agents appeared as attorneys for the individual worker as the labor manager represented the employer. However, in the court reports are many cases involving relations with economic collaterals (third parties). The following arbitration cases really fall into this class.

Two cases involved the difficult question whether an employer could be required, under the agreement, to discharge an employee guilty of an offense against the union. ${ }^{33}$ The arbitrator reached opposite conclusions. In Case 149 the grievance committee of the union disciplined one of its members by a fine and suspension from the shop where he was working. The employer denied the right of the union to require a firm to discharge an employee simply because a violation of union rules had occurred. The union complained that the management was encouraging its employees to defy the union, but specific charges to this effect were not made and the arbitrator therefore ruled this matter out of consideration. On the main question whether the union could discipline its members by removing them from the job, the arbitrator said:

"There is no question that the union must have power to discipline its members. If it cannot do that, then it cannot force them to live up to agreements made by the union with the employers. However, in meting out discipline to its members the union must do it according to the laws of its own organization.:

${ }^{33}$ In the majority of jurisdictions a strike to compel the discharge of non-union employees is not per se illegal. SAYRe, op. cit. supgo note $\mathbf{2 4}$, at $311 \mathrm{n}$. and $318, \mathrm{n} 1$. Massachusetts and New Jersey are conspicuous examples of the opposite doctrine. Plant v. Woods, 176 Mass. 492, 57 N. E. 1011 (1900); Shinsky v. Tracey, supra note 19; State v. Donaldson, 32 N. J. L. 151 (1867). But see Jersey City Printing Co. v. Cassidy, supra note 24.

${ }^{34}$ It is a well settled rule of law that courts will not interfere in the internal affairs of associations, where a remedy is provided by the 23sociation, until that remedy has been exhausted. Wriguriverox, op. cit. supra note 7, \$ 57; SAYRE, op. cit. supra note 4, c. 14; see Brennan v. United Hatters, supra note 24 (withdrawal of plaintiff's membership card held not warranted by the laws of the association and damages awarded for consequent discharge from job); Reihing v. Local No. 52, Brotherhood of Electric Workers, 94 N. J. L. 240, 109 Atl. 367 (1920) (withdrawal of temporary working card, after applicant failed to pass union's entrance examination, not actionable, even though plaintiff lost job and union had closed shop agreement with "greater number" of master electricians of that locality); Malone v. Brotherhood of Locomotive Firemen and Enginemen, 94 N. J. L. 347, 110 Atl. 696 (1920) (worker had right to sue for damages for interference with employment by union which procured his discharge and prevented re-employment, though the employce had not exhausted his remedies as provided in agreements with railroad administration); Mosshamer v. Wabash Ry. Co., 221 Mich. 407, 191 N. W. 210 (1922) (court refused to enjoin railway from putting into effect an order of the union which deprived plaintiff of seniority rights, since the order of the 
It can fine them, reprimand them, suspend or expel them (i. e., from the union) and impose any other penalty authorized by the union's constitution and by-laws which they agreed to obey. But to make suspension by the employer a penalty imposed by the union, is going beyond the union's power of discipline and asking the employer to act in the union's place. The employer is, therefore, within his rights in refusing to take any such action . . . it cannot be held that the union has the right to order the employer to suspend such a member from his job."

In Case 451 a worker was suspended from the union for failing to pay his dues. The employer refused to discharge the man at the request of the union, relying on the ruling in Case 149. The arbitrator ruled:

"The dues are the taxes required to maintain the governmental agencies for the industry set up by the agreement and any individual in whose behalf the agreement was signed who avoids the payment of the tax is violating an obligation assumed by him when the membership of the union voted to accept the agreement . . . In a previous case (149) it was decided that, 'to make suspension by the employer a penalty imposed by the union is going beyond the union's power of discipline and asking the employer to act in the union's place. . . $\quad$ In this case the union has already suspended the erring member before asking for his discharge and could go no further in disciplining him without striking the shop. . . . Since the agreement ties the hands of the union in this respect (stoppages), it must afford to the organization a legal method of enforcing its just disciplinary measures which will be as effective as the refusal of its members to work with an expelled member. - . Unless such a legal method of enforcing disciplinary rules is provided, the agreement would have the effect of weakening the union, members could defy the organization with impunity, and the attempts of the Labor Adjustment Board to hold the union responsible for compelling its members to live up to the provisions of the agreement and to the decisions of the Impartial Chairman would be futile. - . The union may file a complaint with the employer that the member has been so suspended, and if the suspension was regular and not in violation of the agreement, it is the duty of the labor manager to suspend the member from work until he has obeyed the proper disciplinary measures imposed on him. If the labor manager has reason to feel that the disciplinary action taken by the union has not been regular in accordance with its own written rules or has been in violation

union was made according to the customs and by-laws of the association); Chambers v. Davis, 128 Miss. 613, 91 So. 346 (1922) (court refused to enjoin defendants from taking jobs of plaintiffs who were transferred from the regular to the extra list in accordance with union construction of seniority clauses in agreement with railway company, because it was not the "proper function of the courts" to arbitrate disputes between employees as to relative rights "under their contract with the company," there being a vigorous dissent on the ground that the agreement secured valuable rights which the courts should protect). 
of the agreement, then the labor manager mas refuse to suspend the worker" (until the case is reviewed by the Impartial Chair$\operatorname{man}) . .^{35}$

In the first of these two cases $X$ (the grievance committee of the union) penalized $Y$ (a union member) for breach of union rules by a fine and termination of $Y$ 's contract with $Z$ (his employer). The second half of the penalty, however; could be imposed only by inducing $Z$ to suspend $Y$. When $Z$ refused, justifying himself by the agreement, two courses of action were open to $X:$ (1) withdraw Y's fellow workers in that shop; or (2) persuade $A$ (the arbitrator) to construe the agreement so as to put moral pressure on $Z$ to suspend $Y$. The first alternative of direct action was a clear violation of the agreement; ${ }^{3}$ the second alternative failed because $X$ had not exhausted all the remedies in its power.

In the second case $X$ sought to compel $Y$ to pay his union dues by suspending him from the union and terminating his contract with $Z$. Thus $X$ asked $Z$ to cease dealing with $Y$ as a delinquent ex-member of the union. When $Z$ refused, $A$ exerted his moral pressure to make $Z$ conform, using the argument that since $X$ had given up the alternative of direct action and had exhausted its own remedies against $Y, Z$ was morally obligated to conform to $X$ 's request. In the one case, inducing the termination of labor contract was not "lawful," in the second case it was justified to keep the agreement a going concern and to avoid a direct violation by the union. ${ }^{37}$

${ }^{35}$ The ruling in this case was incorporated in the 1922-1925 agreement. Sec. 3: "The employer recognizes the obligation of workers who are members of the union, to pay their union dues."

36 This was the alternative adopted in Cases 151-154, infra at 161.

$3 \pi$ Just what facts constitute legal justification for inducing the termination of a contract terminable at will, which would otherwise be actionable, is not clearly formulated in the cases. Sayre, loc. cit. supra note 24; ibid. op. cit. supra note 24, c. 4, § 2; Huffeut, op. cit. supra note 24. For cases which hold that a trade agreement is a good defense, see Hoban v. Dempsey, supra note 19; Tracey v. Osborne, supra note 26; Mills v. U. S. Printing Co.; Kissam v. U. S. Printing Co., both supra note 19; Searano r. Lemlein, 66 Mise. 174, 121 N. Y. Supp. 851 (Sup. Ct. 1910); Cusumano v. Schlessinger, 90 Misc. 287, 152 N. Y. Supp. 1081 (1915) ; Mraisel v. Sigman, 123 Misc. 714, 205 N. Y. Supp. 807 (Sup. Ct. 1924); Underwood v. Texas Pacific Railroad Co., 178 S. W. 38 (Tex. Civ. App. 1915); Uden v. Schaefer, 110 Wash. 391, 188 Pac. 395 (1920); Harmon v. United Mine Workers, 166 Ark. 255 (1924). Contra: Berry v. Donovan, setpre note 17; Smith v. Bowen, supra note 21; Shinsky v. Tracey, supra note 19 . Compare with Hitchman Coal and Coke Co. v. Mitchell, supra note 24; Callan v. Exposition Cotton Mills, 149 Ga 119, 99 S. E. 200 (1910); Patterzon Glass Co. v. Thomas, 41 Cal. App. 559, 183 Pac. 190 (1919).

The rule adopted in the leading English cases is that a union official is justified in interfering with advantageous relations between emplozers and employees when acting for union purposes. Allen v. Flood [1398] A. 
It should be noted that $X$ 's activity did not deprive $Y$ of all opportunities for employment in the locality, although, if the conduct were repeated with each subsequent Rochester employer of $Y$, the effect might well have been to drive $Y$ out of the market. ${ }^{38}$ The point of interest in the arbitrator's decision in the second case is that conformity to the rules of the union is a legitimate trade interest of all members of the union and justifies interfering with the erring members' vested rights to the job.

(2) Discipline of Officials. Cases involving discipline of employers and union officials form a separate group, because the power of discipline was taken away from the parties directly concerned and lodged with the arbitrator. The usual method of union discipline of employers, i. e., stoppage of work, was taken away by the agreement (Sec. 6). The employer's power to discipline shop chairmen was transferred by supplementary understanding to the labor adjustment board, which, in practice, meant the arbitrator (Sec. 9).

Several cases involved the fitness of a shop chairman who is the union agent on the job, elected by the workers in the shop. The earliest (Case 9) arose when a firm refused to reinstate a shop chairman who had called a shop meeting during working hours and who had struck a fellow worker. The facts were admitted by the shop chairman, who entered a plea of self-defense. The arbitrator stated that his offenses were against his fellow workers for the assault and for loss of time, against the union for violating union rules, and against the employer for causing a stoppage of work. "The main responsibility is on the union to see that men of responsibility and judgment are selected as shop chairmen." Lacking these qualities, the worker was removed as shop chairman, though reinstated as a worker, and the union was ordered to impose a fine of not less than $\$ 10$.

In Case 71 a firm complained that a shop chairman fomented a stoppage to bring pressure on the employer to discharge an inexperienced off-presser hired in violation of an alleged understanding in the shop that off-pressing vacancies would be filled by promoting under pressers. The arbitrator said it was "quite evident that the shop chairman did not understand his duties and that the pressure violated the agreement with the employers." For this violation the pressers were ordered to make up the time lost by working overtime at straight pay. As for the

C. 1; South Wales Miners' Federation v. Glamorgan Coal Compnny [1005] A. C. 239; Sorrell v. Smith [1925] A. C. 700; cf. Conway v. Wade [1900] A. C. 506 .

38 Unless $Y$ conformed to union rules. Cf. Fairbanks v. McDonald, supra note 25; Connors v. Connolly, supra note 26. 
shop chairman who "deliberately intended to bring pressure on the employer by means of a stoppage rather than to take his complaint up through the union," the arbitrator recommended that the union discipline the shop chairman for neglect of duty.

In Case 82 a shop chairman was suspended by the labor manager for stirring up trouble in the shop. The shop chairman counter-charged failure of the management to cooperate. In the hearing it developed that the shop chairman had transacted union business during working hours and had insisted on the discharge of employees whom the firm had a right to employ. Witnesses for the shop chairman testified to the lack of cooperation on the part of the management. The arbitrator felt that there was insufficient cause for discharge, but if the shop chairman continued to invade the rights of others, whether of fellow employees or management, he would be disciplined upon proof of the charges. Hence he was reinstated without pay for time lost while suspended.

In Case 111 the fitness of a shop chairman was challenged on four grounds: (1) He did nothing to prevent stoppages, (2) refused to let two basters continue work when others stopped work, (3) spent half a day on a case involving an assistant foreman, and (4) took up complaints at all hours regardless of the definite time fixed for such business. After hearing the evidence the arbitrator ruled:

"It is quite evident that he is too young and too inexperienced to hold such a responsible position. A shop chairman is an officer of the union just as much as a business agent or an organizer. It is his duty to tell members they cannot stop working when the union agreement provides against it. He should lnow that it is no part of his business to look after the interests of assistant foremen; and when members bring complaints during working hours, he should be strong enough to tell them to come to him at the regular times fixed for receiving complaints."

The arbitrator therefore advised the union that the shop chairman was unfit for his office and a successor should be elected.

These early cases pricked out the methods of handling the discipline of union officials in the shop. Thus in Case 382 the arbitrator could say: "The rule is well established in the market that the labor adjustment board has authority to discipline a shop chairman and not the labor manager," and, applying that rule, reinstate a shop chairman who had been suspended for calling the foreman a liar and refusing to withdraw the remark or apologize, because evidence showed both sides at fault. Similarly when an employer refused to listen to a shop chairman's complaints about division of work, he could not have him re- 
moved for ordering a worker not to do certain work in defiance of the foreman's orders (Case 561). On the other hand a shop chairman should be removed from office for instigating a stoppage to force the firm to hire his brother-in-law because, "Shop chairmen who ask personal favors of a firm show by that fact that they are unfit for the responsibilities of their position" (Case 501). In another case a shop chairman took part in a stoppage caused by the employment of non-union electricians to install electric fans. No union representatives appeared at the hearing, whereupon the arbitrator censured both the shop chairman and the union for "failing to perform their plain duty under" the agreement." (Case 473).

The offenses of the employer requiring discipline were generally of three types: (1) insulting union officials; (2) insulting workers; or (3) flagrant violations of the agreement. Insults to union officials varied all the way from refusing to deal with business agents (Case 179) to assaulting a discharged shop chairman when he came to get his pay (Case 132), and the penalties varied from a reprimand by the arbitrator (Case 207) to a $\$ 50$ fine (Case 220). Similarly where the offense was an insult to the workers, sometimes involving a walkout of the shop in protest (Cases 189-190), the penalty was usually a fine, depending on the seriousness of the offense [insult, racy and abusive language (Cases 197, 445), violence and foul language (Case 613)], although in one case (205) a firm was warned that a repetition of the offense would require the discharge of the foreman.

For a clear violation of the agreement the penalties had the elements of a boycott or threatened boycott. Thus in Case 638 a firm sent work to an unregistered contractor, claiming that this was permissible because this contractor was in the same building where a registered contractor used to be. The arbitrator ruled:

"The excuse offered is too flimsy to be taken seriously. The firm was ordered to withdraw the work (i. e., from the contractor) immediately and must stop all such subterfuges in the future for avoiding their responsibilities under the agreement."

Again where a contractor failed to abolish home work, or pay the minimum wage and time and a half for overtime, he was ordered to live up to the agreement or be removed from the list of approved contractors (Case 658). In Case 741 a fine was imposed for sending models to an unregistered contractor, and in Case 786 a contractor was removed from the list of registered shops where work might be sent because he refused to reinstate a shop chairman when instructed to do so by the arbitrator. Removal or threat of removal from the registered list was a serious 
blow to a contractor's business because of the difficulty of making connection with firms outside the Exchange. ${ }^{30}$

In all these cases the arbitrator, as joint agent of the associated employers and workers, interfered with the probable expectancies of union officials, employers, or workers. The extent of such interference is indicated by the penalties. ${ }^{40}$ The greatest interference was undoubtedly that of inducing contractors or firms to conform by shutting off access to a market (which in one or two cases may have been actually a breach of contractual relationship) or threatening to do so.

(b) Group Discipline-Restraints of Direct Action. Lockouts and stoppages (i. e., strikes) occurred despite the clause of the agreement (Sec. 6) prohibiting them. In dealing with these situations the arbitrator worked out certain methods and principles which may be illustrated by a few cases.

In Cases 151 and 154 a stoppage occurred as an outgrowth of the union's attempt to have the firm discharge a worker for violation of union rules. The union charged the firm's representatives with encouraging defiance of the union. The firm counter-charged that the shop chairman aided and connived in the stoppage. The evidence of the union was that at the time of the stoppage the foreman told the delinquent union worker to stay at work. This was held to be insufficient evidence to prove the union's charges, for the employer was merely protecting his rights. The disposition of the case by the arbitrator is shown in the following quotation:

"Considering that the agreement between the union and the manufacturers is about to expire and negotiations are under way for a new agreement, the Chairman deems it best to leave this discipline entirely to the discretion of the union."

so The above situations were not unlike the common boycott. At the instigation of $W$ (the union), $A$ (the arbitrator) induced $E$ (an employer) to withdraw or withhold patronage from $C$ (a contractor) until $C$ conformed to the sanitary standards and other rules established by the agreement. Insofar as $W, E$ and $A$ had a common interest and unanimity of opinion in acting against $C$, the situation was more like a primary boycott, which is perfectly legal. Mills v. U. S. Printing Co.; Kissam v. U. S. Printing Co., both supra note 19; Pierce v. Stablemen's Union, 156 Cal. 70, 103 Pac. 324 (1909). But in most cases $E$ would have continued business relations with $C$ if $A$, at the instigation of $W$, had not interfered, and this situation is comparable with the secondary boycott, which is generally illegal except in three jurisdictions. Duplex Printing Press Co. v. Deering, 254 U. S. 443, 41 Sup. Ct. 172 (1921).

40 Fines were paid into a fund which, under the administration of the Labor Adjustment Board, was used for the relief of needy workers in the market. The question of liquidated damages versus penalty did not enter. For a case in which the union recovered liquidated damages awarded by an arbitration board for the employer's breach of the agreement see Maisel v. Sigman, supra note 37. 
Nevertheless the arbitrator warned that he would:

"impose proper penalties on every worker who takes part in a stoppage and he will approve the discharge of any shop chairman or other individual who causes a stoppage. Shop chairmen who fail to exert any effort to keep their people at work pending the adjustment of grievances will be deemed to have encouraged the stoppage and will therefore be subject to removal."

This case illustrates the flexibility of the system of adjustment presided over by the then Chairman.

In Cases 186 and 187 two basters stopped work, claiming that the foreman had "indirectly discharged" them by trying to impose unjust conditions after the workers had taken an afternoon's vacation. The rest of the shop followed, and complaint was lodged against four individuals for actively instigating the walkout. The arbitrator's decision was:

"In regard to the two collar edge basters, the Chairman cannot recognize such a thing as an indirect discharge. Either the men refused to work or they were discharged. If the employer tried to impose unjust conditions on these men it was their business to continue to work and file a complaint with their union and with the Impartial Chairman to have the unjust condition removed. Since they had no faith in the ability of the Union and the Impartial Chairman to redress their grievances, and instead chose to use direct action and quitting their jobs, they cannot expect the Chairman to reinstate them."

As for the rest of the shop, those workers who walked out blindly were thought to have received sufficient punishment in wages lost during the time they were out. The four men charged with special activity were treated as special cases. After' examining the evidence, three of them were shown to have been active in instigating the stoppage and were discharged.

"This punishment may, seem too severe, but information has come to the chairman that certain people in the shop have expressed the intention to have another walkout if the decision in this case is not to their liking. Under such circumstances there is no choice except to discharge these three men."

In Case 244 a stoppage occured in a contractor's shop, but the employer refused to take the workers back when the union ordered them back to work. The arbitrator refused to hear the case until the employer reinstated the workers. Thereupon the employer filed a complaint against all who participated in the stoppage and particularly against two alleged instigators whom he wanted to discharge.

Two paragraphs of the arbitrator's ruling deserve quotation in full : 
"It is admitted by both parties that the stoppage was a violation of the agreement meriting punishment. But the emplorer claimed the right to consider that all who took part in it had quit their jobs and he could rehire them or not as he pleased, while the union contended that the employer had no right to punish them in this manner for that would in effect be a lockout which is not justified as a reprisal for a stoppage. The Chairman is of the opinion that when people take part in a stoppage they cannot claim a right to their jobs under all circumstances. They may or may not be reinstated depending on the facts in the case as found by the Chairman or by mutual agreement between the employer and the Union.

"A stoppage cannot be considered mere quitting of work for that involves no violation of the agreement. The employer therefore has no right to assume that the people have quit and to rehire some while others are left out.1 He may, however, discharge them all for taling part in the stoppage and in that case the Union would have the right to request reinstatement on the ground that the discharge was unjustifiable exactly the same as in the case of an individual discharge. But it cannot be assumed that a stoppage automatically acts as a discharge, any more than it does as a voluntary quitting of work. A stoppage must be considered a violation of the agreenent by the people who take part in it, and the union must in every case order the people back to work immediately. In all such cases the employer must reinstate the people and file a complaint if he cares to, unless he has notified them and the Union in advance that he wishes to discharge them all for taking part in the stoppage in which case the Union may appeal to the Chairman to reinstate the people."

Because the employer refused to take the workers back, the arbitrator was

"of the opinion that the employer as well as the people who took part in the stoppage have been guilty of violating the agreement. Had the employer taken them back, then he might have secured redress from the Chairman. As it is the people are punished by the time they have lost, and the employer has the loss of production for his violation."

The charges against the two alleged instigators were not backed by sufficient proof to warrant dismissal, but the arbitrator warned them that repetition of their conduct would justify discharge. ${ }^{42}$

41 In Iron MIolders' Union v. Allis-Chalmers Co., 166 Fed. 45, 02 (C. C. A. 7th, 1908), Judge Crosscup said: "A strike is cessation of work by cmployees in an effort to get for the employees more desirable terms. A lockout is cessation of the furnishing of work to employees in an effort to get for the employer more desirable terms. Neither strike nor lock out completely terminates, when this is its purpose, the relationship between the parties." Cf. MIARTIN, MIODERN LAW OF Tr.1DE UNIONS (1910) $\$ 58$ and cases cited.

12Compare the situation in the above case with that in Miechanies Foundry and Machine Co. v. Lynch, 236 MIass. 504, 128 N. E. 877 (1920), where 
In Cases 192 and 196 a dispute arose over standards of production for off-pressers. The employer threatened dismissal if his demands were not granted; whereupon the pressers walked out. ${ }^{40}$ This was the old way of bargaining. The arbitrator said:

"If either the employer or the men had followed the procedure provided by the agreement, the Chairman would penalize the one that was in the wrong and give redress to the other. . . Since they thought they could do better by taking the law into their own hands, the Chairman cannot help them now. The loss of time and loss of production should serve as a lesson for the future."

Similarly when a section stopped work because it did not like the firm's price offer, "a stoppage is not justified as a method of getting a proper price ${ }^{44}$ any more than a lockout would be justified when the workers ask a price that the employer consider's too high." (Case 294).45 Hence the union was requested to im-

a strike to compel reinstatement of a discharged employee was declared illegal.

13 In Schlesinger v. Quinto, supra note 16, the union obtained an injunction against an employer's breach of an agreement which established the week work system in place of piece work.

14 A stoppage to obtain higher wages than those stipulated in the agrecment, as modified by an arbitration award, was involved in Nederlandsch Amerikaansche Stoomvaart Maatschappij (Holland-American Line) v. Stevedores' and Longshoremen's Benevolent Society, 265 Fed. 397 (E. I. La. 1920). The employer recovered damages for breach of contract (collective agreement). The union, however, was incorporated. This decision illustrates one reason for the opposition of unions to incorporation and also for the fairly general feeling among unionists that trade agreements are, or should be, only morally binding, not enforceable at law. Originally many unions were inclined to favor incorporation, but this is no longer generally true. They fear that incorporation will make it easier for employers to get at union funds. Moreover the mere act of incorporation does not eliminate the difficulty experienced by union leaders in controlling the acts of individual members in trade disputes. The prevailing legal doctrine has been that unincorporated associations, like unions, may not bo sued in the common name in the absence of a statute authorizing such suits, although a different rule is frequently applied in equity. St. Paul Typothetae v. St. Paul Bookbinders Union No. 37, 94 Minn. 351, 102 N. W. 725 (1905). That this doctrine may be discarded by the courts on their own motion is shown by the opinion of the United States Supreme Court in United Mine Workers v. Coronado Coal Co., 259 U. S. 344, 42 Sup. Ct. 570 (1922). The trend of legal opinion seems to be definitely in the direction of holding unincorporated unions suable in their common names. Under this doctrine service of process on the chief official of the union would bo sufficient to "authorize judgment and execution against common property." Sturges, Unincorporated Associations as Parties to Actions (1024) 33 YALE LAW JoURnAL 383.

15 Compare the result achieved in Maisel v. Sigman, supra note 37, with that in Schwartz v. Wayne Circuit Judge, 217 Mich. 384, 186 N. W. 522 (1922), and Schwartz v. Cigar Makers International Union, 219 Mich. 589, 189 N. W. 55 (1922). 
pose a fine because the usual penalty of making up lost time by working overtime at straight pay was impracticable in the busy season. In a number of stoppages for all manner of purposes, from getting better prices or preventing certain workers from getting jobs to forcing personal privileges (Case 501), the arbitrator applied the principle that the party desiring redress must come "into court with clean hands" (Cases 302-303). Penalties variously applied were: (1) Workers ordered to make up lost time by working overtime at straight pay; (2) Workers ordered to pay fines varying from 50c to $\$ 2$ per worker; (3) Workers suffered loss of wages for duration of stoppage; (4) Discharge of workers involved; (5) Shop chairman removed from office; and (6) Workers involved, and union, censured by arbitrator. In the case of lockouts, the employer was penalized by denial of rights of redress, loss of production during stoppage or lockout, or censure by the arbitrator.

Three stoppage cases involving more complicated facts deserve special consideration. In Cases 749-751 intermittent stoppages occurred for obscure reasons, the most definite of which appeared to be the arbitrator's decision fixing a new standard of production for off-pressing. On the first day the whole shop walked out; on the second day the off-pressers stopped work, and they in turn were followed by the second basters. The firm refused to reinstate the basters, and when the off-pressers refused to accept this discrimination in favor of themselves, the firm refused to reinstate the pressers. The firm, having in effect discharged the basters and pressers, petitioned the arbitrator to impose some lesser penalty on the rest of the shop for walking out the first day. In this state of facts we find the following offenses: (1) stoppage of the pressers to coerce a more favorable decision from the arbitrator; (2) sympathetic strike by the basters in support of the pressers, (3) by the pressers against discharge of the basters, and (4) by the rest of the shop in support of the pressers.

The arbitrator's opinion was substantially:

"Such procedure as this of the firm's will not only fail to prevent stoppages but will unintentionally bring the agreement and the impartial machinery into contempt. The most serious offense was that of the off-pressers, for they violated not only the agreement but a specific decision affecting themselves. For this the firm did not think best to impose discharge as a penalty but did try to impose it on the basters for the less serious offense of stoppage in violation of the agreement alone."

After penalizing three of the offenses on its own responsibility, the firm then asked a lesser penalty for the remainder of the shop. 
"The whole series of events should make clear the impracticnbility of varying the methods of procedure in dealing with and preventing stoppages. . . The impartial machinery will be ineffective in such matters if it is used only when smaller penalties are desired by a firm but is excluded from the procedure when the extreme penalty of discharge is to be imposed. Still less can the Chairman be effective if a firm chooses to impose the extreme penalty for stoppage alone but not for stoppage plus disregard of the Chairman's decision. In this case the firm's actions, though not so intended, threaten to bring the machinery into contempt. Consequently the firm's method of securing penalties must be be entirely discarded."

The arbitrator ordered reinstatement of pressers and basters, who were fined $\$ 2$ apiece.

In Cases 798-804 a section of sleeve sewers was discharged by a firm after a stoppage due to a grievance and an altercation with the foreman and labor manager. The latter informed the union that he did not want to take the men back. Nevertheless the union brought the men back and tried to persuade the firm to reinstate them. This was refused, the firm stating that the workers were discharged for walking out in violation of the agreement. The firm then tried to hire new sleeve sewers through the union and by approaching individuals, but without success. Four days after the stoppage the firm filed a complaint "against action resulting in a boycott." Due to illness of various persons a hearing was not held until eight days after this complaint. ${ }^{10}$ The union counter-charged unjust dismissal, though it admitted that the boycott was effective because the discharged sleeve sewers "merely by talking of their grievance" kept "other sleeve sewers from taking the job." $\$ 3$

The arbitrator ruled that the sleeve sewer's had doubly violated the agreement in stopping work and in not taking their grievance to the adjustment board.

"Practice as well. as specific decision of the Chairman (Case 244) has recognized that discharge might be imposed by an employer for such violations. But such procedure sooner or later was sure to lead to such a situation as in this case. .. Whether the stoppage was sufficient ground for discharge or not, the

16 This was an unusual delay in disposing of a complaint, excopt, of course, general wage adjustments. Compare procedural delays in tho law as illustrated in injunction cases and damage suits. An extremo caso is that of the United Mine Workers v. Coronado Coal Co., supra noto 44, in which the original complaint was filed in September 1914 and all phases of the case are not yet finally litigated. Coronado Coal Co. v. United Mine Workers, 268 U. S. 295, 45 Sup. Ct. 551 (1925). The longest period between a temporary restraining order and a final injunction was six years in the Hitchman case.

47 Compare recent New York Supreme Court cases holding that peaceful picketing in the absence of a trade dispute is unlawful. See Comment (1927) 36 Yaíe LAW Journal 557. 
double violation requiles such a reprimand as only a discharge will give. All these sleeve sewers are discharged and both the Union and the firm are to cooperate in carrying out this decision so that the incident shall be closed."

In this case we have the common form of direct action to prevent the formation of contracts which has troubled and divided the courts in picketing and strike cases. Yet there was no evidence of malicious, in the sense of intentional, injury. The sleeve sewers very naturally aired their grievances and the effect of this was a labor boycott. But who can say, from the facts as stated, whether the boycott was a matter of design or conspiracy or merely the incidental effect of normal human behavior? If it were proved that the union deliberately refused to send alternative workers to this firm unless the firm rescinded the discharges of the sleeve sewers, the employer might reasonably claim that the boycott was, in legal terminology, a conspiracy.

The third stoppage case involved both the sympathethic strilie and the secondary labor and materials boycott. In addition it probably went to the "verge of the law" if not beyond, as the agreement was then understood, because it involved interference with the exclusive province of management to solicit and carry out commodity contracts.

In Cases 327-335 the cutters stopped work, claiming that the firm was doing strike work from New York, where a lockout and strike involving members of the Amalgamated was being carried on. The arbitrator ordered the cutter's to return to work pending investigation, because "a stoppage is not justified merely because the workers think such work is being done." The employers, speaking through legal counsel, raised the question whether the Impartial Chairman had jurisdiction over the union's complaint."s This question was answered affirmatively by the arbitrator.

"The underlying principle of the agreement is that any grievance of the workers will be heard and decided in accordance with the rules laid down in the agreement, and only the Impartial Chairman has authority to decide whether a question is covered by the agreement or not. The agreement says that all disputes arising under the agreement shall be submitted to arbitration and there is no doubt that a stoppage because the workers think they are asked to work on goods for a house where there is a lockout or a strike is a dispute arising under the agreement. The Chairman is therefore of the opinion that it is his duty to determine the fact whether the work in question is really of

ss It will be recalled that under the Rochester agreement the decision of the arbitrator as to jurisdiction was final. Sujria note 4. 
this character and the agreement gives him authority to make decisions in all such cases." 49

Having taken jurisdiction of the dispute, even though it involved the selling policy of a firm, the arbitrator faced two questions: (1) What does the agreement require if this was "strike work?"; (2) Was the work in question "strike work?"

On the first question the arbitrator held:

"It can not be assumed, that when this union signed the agreement it entered into any arrangement which would compel its members to work for its own destruction. When employers in this or in other cities are engaged in a fight with the union, the members of the union can not be expected to do the work for those employers with whom the union is fighting and so help to destroy their own national organization which is a party to the agreement in Rochester. The members of the Clothiers' Exchange were well aware of this when the present agreement was entered into, and it must be held that the agreement reserves

49 The willingness of the arbitrator to assume jurisdiction over an ap. parently borderline case may be compared with the similar attitude of courts toward disputes arising under collective agreements. For example, compare the majority and dissenting opinions in Chambers v. Davis, supra note 34, and the opinion in Hudson v. Cincinnati Ry., supra note 7, with the opinions in Maisel v. Sigman, supra note 37, and Hoey v. Now Orleans Ry., supra note 28 . The trend of judicial opinion, particularly in Now York, seems to be in the direction, on one ground or another, of construing trade agreements as contracts and consequently of giving remedies in disputes arising thereunder. See Clark, Collective Bargaining in the United States of America (1927) 15 International Labour Rev. 197; Clark, Legal Effect of Collective Agreements (1921) 12 MoNTHLY LABOR Rav. 416; Fuchs, Collective Labor Agreements in American Law (1925) 10 ST. Lours L. REv. 1.

One may well surmise how the courts would have treated this assumption of jurisdiction by the arbitrator if, as a result of this award, eithor party to the agreement had sought to test its validity by legal action. The awards under the Rochester agreement fall within the classification of common law arbitration. If the collective agreement is construed as a contract and is also construed to cover such disputes as the one involved in Case 327 above, the common law doctrine is clear and of long lineage that such an award will be enforced barring other faults. 5 C. J. $\$ \S 389,555$ et seq.

Illustrating the judicial treatment of arbitration awards in pursuance of a collective labor agreement are the following cases: Mastell v. Salo, 140 Ark. 408, 215 S. W. 583 (1919); Maisel v. Sigman, supra note 37, with which may be compared Gregg v. Starks, $188 \mathrm{Ky} .834,224$ S. W. 459 (1920); Chambers v. Davis, supra note 34; Malone v. Brotherhood of Locomotive Firemen and Enginemen, supra note 34; Hoey v. New Orleans R. R., supra note 28 . In the Hoey case the arbitration board was authorized by statute. In the Gregg and Malone cases the railway board of adjustment functioned under authority of the Director-General of Railroads, who, in turn, derived his authority from an Act of Congress. Presumably, therefore, the arbitration decisions in these cases were not awards in the common law sense. 
the right to members of the union not to work on any so-called "strike work." so

On the second question both sides submitted their evidence and the Chairman himself made an investigation of the facts. The employers presented evidence

"to show that it is a bona fide retail order for" a retail chain of stores which has always bought goods in Rochester and in other markets besides getting a good deal from the New York manufacturer who has an interest in these stores. The Exchange contends that its members make goods for retailers and as long as this order is from a retailer for goods to be sold in the stores and not for the manufacturer whose people are locked out or on a strike, this can not be considered 'strike work'."

The union contended "that the chain of retail stores is operated merely as a department of a manufacturing firm in New York which has locked out members of the Amalgamated from its shops and which, it is charged, has openly stated that its purpose is to destroy the union ... and that goods and patterns were shipped up by this house" to the Rochester firm.

The arbitrator's investigation ${ }^{51}$ disclosed

In The privilege of union members to refuse to work on "strike worl:" and to strike rather than do so was upheld in Iron Miolders' Union v. AllisChalmers Co., supra note 41. Cf. Pacific Typesetting Co. v. Typographical Union, 125 Wash. 273 (1923), in which the fact that plaintiff's work was not "strike work," in a strict sense, was a material point in the court's decision to award damages against the union.

51 Independent investigation by the arbitrator was a not uncommon method of getting at the relevant facts of a dispute. The methods of finding facts varied with the circumstances of the case. If the adcquacy of a rate for a particular operation was disputed, the arbitrator might go into the shop and observe the operation himself; he might appoint an investigating committee composed of representatives of cmployers and workers not directly involved in the controversy; he might informally ask the opinion of foremen or production supervisors in other firms, or of union agents or shop chairmen who had worked or were working on the operation in question. In cases $327-335$ the arbitrator happened to be a former arbitrator in the New York market and hence knew something of the surrounding circumstances. In any event the arbitrator was not obligcd to rely solely on the facts brought in evidence by the parties to the immediate dispute as in the case in court proceedings.

In People v. Epstean, 102 Misc. 476, 170 N. Y. Supp. 68 (Ct. Gen. Sess. 1918), which involved the validity of a uniform price list for photo-cngraving under the New York anti-trust statute, the judge, at the suggestion of the parties, visited a shop and watched the process of maling a photoengraving plate. He reached the conclusion that "photo-engraving is not a commodity," within the scope of the statute, but "is rather to be regarded as an art or process, . . . work, labor and services." It is at least a reasonable inference from the opinion that the judge came to this conclusion mainly as a result of his personal investigation. Compare Standard Engraving Co. v. Volz, 200 App. Div. 758, 198 N. Y. Supp. 881 (1st Dent. 1922), in which a strike to force employers to conform to a union rule 
"that piece goods were sent up by the retail stores which evidently came from the New York manufacturer. . . No patterns were sent in this way, but a coat or two were sent up as models for the order. . . The chain of retail stores is a separate corporation with different officers and directors from the New York manufacturing firm but this firm does have a financial interest in the corporation."

The arbitrator therefore ruled:

"In view of these facts the employer had justification for assuming that he was taking a bona fide order from a retailer. On the other hand the fact that the retailer received piece goods from the New York manufacturing house which has an interest in the retail stores and which has offices in the same building with the offices of the retail corporation raises the suspicion - that some of the finished goods might be turned over to the same manufacturer; and if that happened the union members would have a right to refuse to do this work. In order to avoid any difficulty in this regard and the strikes and stoppages which might result from it, the Chairman is of the opinion that the workers should finish out whatever work has already been cut, provided the rest is sent back and they are required to do no more of it." 52

In other words, if $A$ (a manufacturer) is engaged in a dispute with $B$ (a union), the members of $B$, wherever located, are justified in refusing to work for $C$ (an employer operating under an agreement with $B$ ) on goods destined for $D$ (a retailer having financial relations with $A$ ), in order to coerce $A$ to conform to the demands of $B$. Moreover this refusal of $B$ to work for $C$ is justified in the absence of an overt act showing that $A$ will benefit directly from the contract between $C$ and $D$. The justification rests on the broad ground of the common interest of all members of $B$, by whomever employed, in the struggle between $A$ and the New York members of $B .^{53}$ The action of the Rochester members of $B$ was a sympathetic strike against $C$ in order to break a contract between $C$ and $D$ which might in the future have directly benefited $A$. If $A$ had no financial interest in $D$, the situation would clearly have been that of a secondary boycott, which was, in effect, the argument of $C$. In view of the financial

establishing a minimum base price for photo-engraving was held to have been properly enjoined. In this case the opinion of the court dealt almost entirely with legal rules of statutory construction.

52 This decision, with others, led to the narrowing of the arbitrator's jurisdiction in the 1922-1925 agreement, supra note 5 . The reason for this restriction appears to be that of protecting the arbitrator against having to make decisions on basic industrial policy for which the parties themselves should accept full and mutual responsibility. SEventh BIENNial Report of General Executive Board of Amalgamated Clothing WorkERS (1926) 25-27.

${ }^{53} C f$. Justice Holmes' dissenting opinion in Vegelahn v. Guntner, supra note 24 , at 107. 
relationship, the situation was practically that of a primary boycott. If this financial connection between $D$ and $A$ were absent or overlooked, the union would have accomplished by means of the agreement and the adjustment machinery in Rochester what the United States Supreme Court declared illegal in the Dupler case..$^{\prime \prime s}$

(c) Lay-Off and Permanent Reduction of Force. The above cases illustrate the tendency under the Rochester agreement to establish for the worker certain vested rights in his job. These rights were protected by the arbitrator against unjustified invasions by immediate or possible employers, by employers or workers outside the agreement, and by fellow-workers. The object was to promote efficiency and orderly adjustment of disputes by making the worker feel that his job was secure and his future expectations reasonably certain. ${ }^{55}$ The agreement was in no sense, however, a guarantee of continuous employment. Irregular employment was a risk, proceeding from fluctuations in commodity markets, which affected not only the tenure of the job, but also the certainty of earnings on the job; yet the agreement contemplated only the prevention of discrimination, favoritism and unequal treatment in the adjustment of vested jobrights to this risk.

The cases in which these situations arose group themselves under the two headings of lay-off and permanent reduction of force. The agreement (Sec. 7) specified that during slack times work should be divided equally among all workers "as far as practicable." ${ }^{56}$ In some instances workers demanded a particular method of dividing the work, but the arbitrator held that the

54 Duplex Printing Press Co. v. Deering, supra note 39.

55 The same aim underlay the adjustment of disputes regarding earnings on the job, though the protection of earnings was more a matter of standardization, i. e., the application of the formula "equal pay for equal effort," with some adjustment of earnings levels to accomplish other purposes (such as equalization with other competing markets, standard of living, discouragement of home work). The wage cases are too numerous to summarize here. See Morehouse, Development of Industrial Law in the Rochester Clothing Market (1923) 37 QUAR. J. of Ec. 257.

56 In Minasian v. Osborne, 210 Mass. 250, 96 N. E. 1036 (1911), a strilie to abolish a system of helpers which resulted in unequal division of worl: during slack periods was not enjoined. In National Association of Window Glass Manufacturers v. U. S., 263 U. S. 403, 44 Sup. Ct. $14 S$ (1929), an agreement to divide factories into two groups and operate each only during certain periods of the year did not constitute an unreasonable restraint of trade. In Benito Rovira Co. v. Yampolsky, 187 N. Y. Supp. 804 (Sup. Ct. 1921), the plaintiff laid off men and the defendant, representing a committee of the plaintiff's employees (no union was involved), told plaintiff that the workers would strike unless all were retained or work was divided equally. The court ruled that the strike was illegal and should be enjoined. 
employer was privileged to arrange the division to suit his production requirements so long as each worker received an equal share (Case 288). But the employer could not divert work from one individual to another (Cases 295 and 623). Yet if one worker lost half a day more than the others on his operation, he had no complaint.

"As the agreement provides for equal division of work 'so far as practicable' the slight difference in the case of this man comes within the differences arising from considerations of practicability" (Case 723).

Moreover the union could not invoke the equal division of work principle during busy seasons against the reduction of an overmanned section, for that would lead to a permanent over-supply of labor (Case 385).

In some instances particular employers guaranteed their employees against a lay-off ${ }^{57}$ and disputes arose concerning the application of these spécial agreements. In one case (51) such an agreement was claimed by the workers as justifying payment for time lost. The arbitrator could find no certain evidence of the existence or terms of such an agreement, but required the employer to pay for time lost because he laid off the whole shop to avoid paying for the idle time. In another case a verbal agreement to pay for idle time was proved to exist (Case 55). The workers claimed this required paying for idle time when laid

57 On the legal duty of the employer to furnish work, see 2 WiLuston, op. cit. supra note $3, \S 1015 ; 26$ Cyc. 1017 and cases cited. Under a term contract there appears to be often an implied legal duty to furnish work (or compensation) for the term of the contract, omitting such complications as impossibility of performance due to bankruptcy. Under a contract at will there is no such obligation. Where payment is by the piece, the law recognizes no such duty unless it is expressly stipulated, or the custom of the industry clearly requires the employer to furnish work or pay for idle time. Texas Central R. R. v. Newby, 41 S. W. 102 (Tex. Civ. App. 1897).

In Schwartz v. Wayne Circuit Judge, and Schwartz v. Cigar Makers International Union, both supra note 45 , the plaintiffs were cigar manufacturers who had been operating under a union agreement. The union agreed to a cut in wages in return for an agreement by the employers "to furnish employment to their shop capacity for a year" to members of the union only. Instead, the plaintiff hired some 200 non-unionists and when a strike ensued to enforce compliance with the agreement, the plaintiff asked for an injunction restraining picketing, interference, etc. The union filed a cross-bill asking an injunction restraining the breach of the agreement. The union's request was denied and an injunction granted to the employers. "In the instant case the practical effect of the decree (i.e., for the union) is to control the conduct of the business of the plaintiff ..." Compare Blum \& Co. v. Landau, 155 N. E. 154 (Ohio 1926), in which an employee recovered wages due under an unemployment insurance clause of a collective agreement. 
off through no fault of their own "s; the employer claimed that such payment was due only when the lay-off was the fault of employer. In this instance, the absence of 5 out of 18 buttonhole makers caused the lay-off of the other workers. The arbitrator ruled that since neither party anticipated situations like this, the verbal agreement should not hold. But "it is the responsibility of management to keep a regular flow of work going through the shop and absences constitute one of the difficulties that management must calculate in advance on overcoming." However, the Chairman expressed the belief that as a matter of managerial policy, the workers should be paid for time lost because the verbal agreement was made to reassure employees that they would not be working themselves out of jobs by increasing or maintaining production early in the season, and because it was desirable to avoid giving them this impression. 59

But there is a vast difference between temporary separation from the opportunity to work and a permanent separation, such as occurs in permanent reductions of force. When only one section is involved, the difficulties in finding other jobs with the same or other firms are not so great. But when the entire shop is abandoned because it is unprofitable the difficulties are much greater. Two decisions will illustrate how these situations were dealt with.

In Case 594 ten cutters were given a week's notice of discharge on account of permanent reduction of force. The arbitrator held that, instead of immediate discharge, work should be divided until the union found jobs for the surplus cutters, who were to be the first source of supply to the union. In Case 698 a firm's announcement that one of its shops would be closed indefinitely was charged with being a violation of the spirit and letter of the agreement. The arbitrator ruled:

"The issues in this case are not covered by the letter of the agreement but by the unwritten understandings and established

${ }^{58}$ Compare Illinois Central R. R. v. Baker, 155 Ky. 512, 159 S. W. 1160 (1913), in which miners wha had been laid off by a mining company on account of negligence of the railroad in failing to supply the company with cars (for which negligence the mining company obtained damages from the railroad) sought unsuccessfully to recover damages from the railroad for wages lost during lay-off.

5a In Mloody v. MIodel Window Glass Co., 145 Ark. 197, 221 S. T. 496 (1920), the court upheld the employees' claim under a national agreement for wages while waiting for work. $C f$. IIastell v. Salo, suma note 49 (worker recovered wages awarded by arbitration under agrcement, though worker was uninformed as to his rights in the matter until agents of his union took up his case); Gulla v. Barton, 164 App. Div. 298, 149 N. Y. Supp. 952 (3d Dept. 1914) (worker recovered difference between wages paid by employer and wages due under agreement with union). See also Keysaw v. Dotterweich Brewing Co., 121 App. Div. 58, 10j N. Y. Supp. 562 (4th Dept. 1907). 
practices of the market. These have recognized employers' rights to a permanent reduction of force, to close down a shop and to enlarge a shop; ${ }^{60}$ and the employees rights to preference in em-

60 The right or privilege of an employer to close down an unprofitablo shop was involved in two recent cases. In Welinsky v. Hillman, 185 N. Y. Supp. 257 (Sup. Ct. 1920), the Amalgamated Clothing Workers had struck to compel an employer to continue the manufacturing department of his establishment, which he had determined to abandon. Plaintiff asked for an injunction restraining the strike. This was granted on the ground that the strike was unjustified "coercion in support of a demand which tho employees had no right to make." The court said: "I am not insensible to the hardship to old employees thus suddenly thrown out of work, or of the loyalty of their fellow workers, who seek to come to their rescuo; but I see no justification under the law for their present attempt, or the attempt of their union, to compel the plaintiff to continue their employment. Such situations may very well suggest doubts and problems to the student of social science; but in the present state of our law, which is adapted to prevailing conceptions of individual rights, I think there is no doubt about the decision which must be given here." A similar situation was involved in Maisel v. Sigman, supra note 37, in which the plaintiff resigned from the employer's association in order to reorganize his business, eliminating much of the "inside manufacturing" which was controlled by agreement between the union and the employer's association. After a strike, a now agreement was made, including arbitration and liquidated damage clauses and restrictions on the employer's tendency to contract out his work. For breach of this agreement and refusal to abide by an arbitration award, tho union recovered liquidated damages.

In Rutan Co. v. Local No. 4, Hatters' Union of America, 97 N. J. Eq. 77, 128 Atl. 622 (1925), the plaintiff found that his "making shop" was unprofitable and that he could purchase hats "in the rough" cheaper than ho could make them. He therefore closed down the shop and discharged tho workers. The employees in the finishing shop of the samo firm struck in sympathy. Plaintiff asked for an injunction, claiming that the strike was for the purpose of forcing him to re-open the abandoned shop. The defendant union claimed that the strike was in pursuance of their own interests as expressed in a union by-law that no manufacturer should bo given a union label who had a "making shop" and bought hats in tho rough, unless the making shop was run to capacity. The opinion of tho court is interesting. " ... if . . the purpose of a strike is, and as tho complainant contends it is here, to compel an employer to run his shop against his will, and to his injury re-employ his discharged hands, for whom he has no use, then the strike is unlawful, for the union has no right to prevent employers of labor from profitably prosecuting their business." Yet the court found that the proof in this case did not show such unlawful purpose, although admitting that the plaintiff "may have to re-establish its plank shop, i.e., making shop, or go out of business altogether." " . . . for such misfortune the members of the union disclaim responsibility, and rightly. They were not under contract to work; they have done nothing more than refrain from working; they have not prevented the complainant from procuring others to take their places, and none of the usual strike tactics has been resorted to to deter others from taking their places, nor have they in any way interfered with the complainant in the carrying on of its business in its own way. In fine, their attitude has been simply one of hands off and let the complainant get along as best it may without them. This attitude is not open to judicial criticism." 
ployment by firms for which they have worked ... except as limited by the permanent reduction of force. . . These preferential rights apply primarily to the same or similar operations as those performed in the old shop, and a former employee in Shop No. 3 is to be in no sense a new employee or on probation in the rest of the plant when given a position at his former operation. If an employee is offered and accepts a position on an entirely new operation, he may be treated as on probation on the new work. If he fails to make good he by no means loses his preferential rights to a position on his original operation when open." c2

(d) Introduction of Ifachinery. The tenure of the job was threatened, of course, by every change in managerial policy, but changed methods of manufacturing constituted the most serious threat of all. The introduction of machinery tended not only to displace the worker from a particular job but also to destroy the skill, acquired through long experience, which was the chief asset of the worker claiming a favorable differential in wages.

The agreement specified in Section 5:

"The right of the employer to make changes in shop management and methods of manufacturing is recognized, such changes to be made without loss to the employees directly affected."

In the situations that arose, the difficulty was to protect this right of the progressive employer while at the same time protecting the worker's skill and job. Two cases only need be cited to show how the arbitrator construed the phrase "without loss to the employees directly affected."

In Case 346 an employer introduced new machinery which split the off-pressing operation into several parts. Hitherto offpressing had been done entirely by hand and was considered the most skilled of the pressing operations. The union complained that the machines were improperly introduced and that the change should not have been made because the off-presser's' slill was thereby taken away. The employer's argument against the union's first complaint was that the shop was new and all the pressers could not be called to work at once, and that all the pressers and the shop chairman knew the machines were in the shop and were openly told of the proposed change in work. Evidence showed that the pressers worked from three to six weeks without complaint, so that, while the matter was not tactfully handled by the employer, the shop chairman knew of the new methods and therefore could not complain of improper inducement.

01 As to seniority rights under a trade agreenent after a layof, see Mosshamer v. Wabash Ry. Co., supra note 34; Dickinson v. Brotherhood of Locomotive Firemen and Enginemen, unreported case, District court, 2nd Judicial District, Division 3, City and County of Denver, Colo. (1925). 
The arbitrator ruled that there could be no dispute as to the right of the manufacturer to introduce new machinery provided the workers did not suffer thereby, saying:

"There is a certain amount of loss of skill from this splitting of the operation but that is inevitable and in place of it the worker gains the efficiency that comes from specialization."

Furthermore other operations in the market had been divided, and the pressers in this house were not entitled to special consideration or a favored position in the market.

The skill of the worker may be taken away in the interest of industrial progress. But an employer may not invoke the right to change manufacturing policies as a cloak for the arbitrary displacement of workers from jobs (Case 306) ; he should maintain earnings and keep the worker on the job until another place can be found for him by the employer or the union.

\section{RELATION OF THE LAW TO EXTRA-JUDICIAL PROCESS}

Flexibility was the outstanding characteristic of the system of "industrial jurisprudence" ${ }^{2}$ worked out in the Rochester clothing market. The terms of the trade agreement were adapted by both parties and the arbitrator to the circumstances of each case. There were no rigid rules regarding admissibility of evidence or the weight to be attached to particular facts. Any relevant facts could be introduced by either party and the arbitrator could ask for or seek additional facts on his own initiative. ${ }^{\text {s }}$ Procedure was informal; the jurisdiction of the arbitrator was broad; he was in close daily contact with the technical problems involved and with the persons charged with administering the agreement. The interplay of personalities-the psychological element which is so important a part of employer-employee relations-in short, the "industrial politics" of of the market could thus be taken into account in finding a workable solution of disputes. Finally, one may note the adaptability of the sanctions at the arbitrator's disposal ${ }^{65}$ to the practical requirements of

62 Ernst, The Development of Industrial Jurisprudence (1921) 21 CoL. L. REv. 155.

${ }^{63}$ A court of law relies, almost necessarily, on the facts brought out by counsel who are themselves playing the game according to rules of law. Even when the lawyers seek to bring pertinent industrial facts to the court's attention, it is often difficult to get them into the record. Rules of evidence and of pleading, interpreted by the court, are frequently insurmountable obstacles. Examine the history of Michaels v. Hillman, 111 Misc. 284, 181 N. Y. Supp. 165 (Sup. Ct. Sp. T. 1920); 112 Misc. 395, 183 N. Y. Supp. 195 (Sup. Ct. Tr. T. 1920).

${ }^{64}$ As in Cases 151, 154, supra at 161.

65 As in the stoppage cases, sura at 161 et seq. 
each situation. ${ }^{66}$ Although certain remedies came to be applied to certain types of wrongs, there were no hard and fast rules governing the use of penalties.

Nevertheless, flexibility of "substantive rights" or remedies would not accomplish the underlying purpose of stabilizing labor relations in the market if the common rules established by mutual agreement or by decision of the arbitrator were not rooted in the customs and usages of the parties themselves. These customs and usages grew up in the day-to-day bargaining over the terms and conditions of the morrow's jobs. Some of the customs were of recent origin, some of long standing, and some, indeed, were claimed merely as talking points for a more obscure aim not easily found without probing beneath the surface. Both employers and workers acted according to these customs and usages. When they clashed, as they often did, it was the arbitrator's task, if mutual adjustment failed, to explore the technological, business, political, and other factors in the dispute. Bearing in mind the desirability, from the standpoint of efficiency, of keeping the bargaining process going, he might approve the customs of the employer or of the workers, or might find a middle ground which would prove acceptable to both sides. Conformity to the common rules of the market was obtained by the moral sanction of threatening offenders with the ill-will of fellow workers or fellow employers, or by the economic sanction of withholding the privileges of the job or of the continued service of employ-

${ }^{66}$ To a certain extent the law recognizes that both legal and cquitable remedies can not be used satisfactorily by courts in all situations. The rise of equity courts as supplements to the common law courts is but one illustration. Even in equity, specific performance of perzonal service contracts has always been found impracticable, though recently there has been a tendency to secure enforcement indirectly by the use of injunctions. Poneroy, A Treatise on the Specific Perforsunce of Contracts (ed cd. 1926) $\$ \$ 22,303-312$. In this country attempts by legislatures to restrict the use of injunctions in labor disputes have been rebufted. Truax v. Corrigan, 257 U. S. 312, 42 Sup. Ct. 124 (1921). In England, however, the Trades Disputes Act of $\mathbf{1 9 0 6}$ eliminated both legal and cquitable remedies in disputes between employers and employees and between worlimen growing out of employment. However, in National Sailors' and Firemen's Union v. Feed [1926] $1 \mathrm{Ch}$. 536, Justice Astbury declared in a dietum that the general strike of MIay, 1920 was illegal, being outside the scope of the Act of 1906. Since the general strike, there has been much discussion of an amendment to the Act of 1906 so as to protect the consuning public more adequately. See Goodhart, The Legality of the Guacral Strilie in England (1927) 36 YALE LaW JounNaL 404. Despite the desirability of American legislation similar to the Trades Disputes Act, it is doubtiul whether such a statute would long survive judicial interpietations of constitutional law. In Massachusetts proposed legislation made tortious act 3 in behalf of a trade union or employer's association non-actionable. An advisory opinion held the proposed statute unconstitutional. Opinion of the Justices, 211 Mass. 618, 98 N. E. 337 (1912). 
ees. This is a task requiring intimate knowledge of the industry and of the psychology of employers and employees.

This process of extra-legal or extra-judicial adjustment of employer-employee relations rests on a fundamental difference between commodity-transactions and job-transactions. In the job-transaction the worker delivers something that is inseparable from the body and will of the worker; in a commodity-transaction there is an exchange of things separable from the person. This distinction was implicit in the administration of the Rochester agreement. It raises two questions: (1) Are the courts of law-indeed is our whole legal system-equipped for the task of working out and enforcing the customs and common rules necessary to achieve that degree of stabilization of the labor market which will contribute most to economic efficiency and welfare? (2) Should not the courts allow to extra-judicial adjustment of labor relations at least the same freedom from legal consequences that is increasingly allowed in the arbitration of commercial relations ? 67

67 Cohen, The Law of Commercial Arbitration and the New Yorl Statuto (1921) 31 YALE LAW JourNal 147; Ernst, op. cit. supra note 62; Raromr of Commitree on Commerce, Trade \& Commercinl LaW to AMERican Bar ASSOCLATION (1925) especially recommendations No. 5, 6 and 7. In following the recommendations of the Bar Association committee-that arbitration awards under "contracts" between unions and employers' associntions be enforced at law if the agreements are "in the public interest"-thero is danger of re-introducing the inflexibility and impractical classification of labor contracts with commodity contracts which many arbitrotion agreements seek to avoid. It would therefore seem desirable to discuss and perhàps experiment with some such safeguards as the following: (1) No judicial interference until the remedies under the arbitration agreement have been exhausted; (2) Judicial acceptance of arbitrator's award as conclusive of the facts and also, as far as possible, conclusive of the law; (3) Remand the case to the arbitrator if, subsequent to his award, one of tho parties seeks to introduce new evidence in an action at law. This proceduro has been deemed necessary to make effective the work of such administrative bodies as the Federal Trade Commission and certain Public Utility Commissions-the Railroad Commission of Wisconsin, for example. Wis. Stat. 1923 , c. $196, \S 44$; (4) Designation of one court in each jurisdiction to hear all cases appealing from an arbitration award. $C f$. Wis. Stat. 1923, c. 196, $\S 41$ in the case of the Railroad Commission. If we are to have judicial review of arbitration awards, it seems reasonable that the parties should have the benefit of judicial opinions that are founded on tho familiarity with technical details which is most likely to result from specialization. 